\title{
The Possibility Requirement in Plato's Republic
}

\author{
Mason Marshall
}

The main view I argue for here is not entirely new. Myles Burnyeat (1999; cf. 2000,64 ) has already put forward a thesis much like mine, maintaining that for Socrates and his interlocutors in the Republic, unless they demonstrate that the aristocratic city they have built in speech is 'a practical possibility' in the sense that 'a reasonable approximation to it is a practical possibility', the effort they have put into describing this city will have been 'idle daydreaming, mere wishfulfilment' (300). ' Plus, there was some degree of precedent for Burnyeat's thesis even when he first articulated it. ${ }^{2}$ Nonetheless, he was right to say that the repeated claim in the Republic to the 'practicability' of the aristocratic city had 'not been examined with the care that is due to it' (1999, 301; citing 375c-e, 415c-d, 423d-424a, 425d-e, 450d, 452e-453c, 456c, 457a, c, d-e, 458a, b, 466d, 471 c-e, 472b-473b, 473c-e, 485a, 499c-500e, 502a-c, 520e-521a, 540d, 592a). Focusing mainly on a set of different, related themes, he did not fully develop his thesis about practicability. It was contentious enough, and since then it has been heavily downplayed and even flatly rejected in some quarters. ${ }^{3}$ Annas 1999,80 is unequivocal: 'There are passages [in the Republic] which make it clear that it is of no importance whether the ideal state can exist or not' (cf. Blackburn 2006, 49). And other commentators talk either as if the practicability issue is of little or no concern to Plato or as if it should be of little or no concern to us. ${ }^{4}$

Burnyeat, though, is basically correct: on Socrates and his interlocutors' terms, a city built in speech is not the best polis unless it is practicable-or, as I shall put

\footnotetext{
${ }^{1}$ Whenever I mention the aristocracy or the aristocratic city in the context of a particular stage in the Republic, I refer to kallipolis under discussion in that stage of the dialogue. Otherwise I refer to the kallipolis described by the dialogue's end. All I ever mean by 'political' in this essay is 'explicitly about cities, including regimes'. All references to Plato's text are to Burnet's edition and translations of the Republic are based on Bloom 1968.

2 Worth considering are, e.g., Laks 1990; Reeve 1988, especially 110; Annas 1981, 185 (which has to be viewed in light of 187, 296); Moline 1981, 45-46; White 1979, 152.

${ }^{3}$ See, e.g., Annas 1981, 187, 296; Guthrie 1975, 457n1, 464-465, 469-470, 483-486, which includes a fair amount of other relevant bibliographical information. Perhaps like Annas 1981, 185 (on which see Laks 1990, 214), interpreters such as Demos 1957, 166nl have taken the view that in the Republic 'Plato vacillates on the question whether his ideal state is capable of realization'.

${ }^{4}$ Schofield 2006, 239 maintains that there is 'crystal clear' indication in the text that 'our focus' in reading the Republic should be not on 'the issue of possibility or impossibility' but on 'the idea of community (koinônia)' - the idea 'that sharing is what makes a city a real or a good city'. Brown 2000,14 holds that in the dialogue 'actual feasibility' is ultimately presented as 'an unimportant concern (472d2)' (though perhaps by 'actual feasibility' Brown should be taken to mean something like 'attainability here and now within a particular society').
} 
it, possible. ${ }^{5}$ To be sure, Socrates and his interlocutors shift somewhat at $472 \mathrm{~b} 3$ 473 b3. Prior to that passage, they talk as if the aristocratic city is possible if and only if it could come to be (or, exist)-in other words, if and only if it could be replicated in the phenomenal world. And after $472 \mathrm{~b} 3-473 \mathrm{~b} 3$, they talk as if the aristocratic city described before that passage is possible if and only if it could be (at least) approximated closely enough in the phenomenal world - that is, if and only if a similar enough city could come to be, even if the original polis itself could not. But at any rate, insofar as they argue for the justice of the aristocratic city, an integral part of the task they take up is to show that there could be a close enough phenomenal approximation to the original polis.

Granted, in one respect Socrates and his interlocutors' claim that there could be such an approximation is more modest than we might suppose at first. As Burnyeat 1999, 306-307 correctly notes, they make their claim 'not with a view to what could be done in Athens or Syracuse, tomorrow or the day after, but from a standpoint of both temporal and geographical neutrality' (307; see, e.g., 502b13 ). Accordingly, the claim is not that the requisite approximation is attainable for some particular society, ${ }^{6}$ but simply that there could be a close enough phenomenal approximation somewhere sometime. In other words, what they must argue successfully is that an approximation of that sort is not precluded by a certain set of constraints, namely, either the constraints of the phenomenal world or the conjunction of the constraints of the phenomenal world and the constraints imposed by the immortal soul, meaning the psuche which survives the death of the human body. ${ }^{7}$ In claiming that a close enough approximation could come to be, Socrates and his interlocutors do not commit themselves to saying that any particular political proposal voiced in the Republic is worth trying to put into practice, at least anytime soon. There would be no inconsistency in making their claim about possibility while also maintaining, for example, that the makeup of every society in the foreseeable future will preclude a close enough phenomenal approximation.

Yet Socrates and his interlocutors do take on the task of arguing that there

5 Whenever I say 'on Socrates and his interlocutors' terms, $p$ is the case', all I mean is that Socrates and his interlocutors treat $p$ as true, talking as if $p$ is the case; whenever I say that they talk as if $p$ is the case, what I mean is that they are aware that they talk that way. When 1 say that Socrates and all his interlocutors in the Republic agree with each other on a particular view or argument, all I mean is that after one character claims or implies that a particular view is true or that a particular argument is sound, either none of the characters ever voices any reservations about it or every character who does voice reservations ends up voicing his assent and never retracts it.

${ }^{6}$ And of course, neither does the claim concern how likely it is that a close enough phenomenal approximation will come to be (cf., e.g., 502c6-7,540d2-3).

${ }^{7}$ Presumably, the constraints of the immortal soul are also included if in the Republic the immortal soul is supposed to contain not only reason but also spiritedness and appetite. I mean to take no position on the issue of whether it is (on which see Lorenz 2006, 36-38 and Gerson 2003, esp. 124131). Burnyeat 1999,306 can seem to mean that the constraints of human nature are the only constraints at issue in the conversation between Socrates and his interlocutors. But at the least (even in light of 456b12-c1 and 485a4-8; see Burnyeat 1999, 306 with 306n 17; cf. White 1979, 142), presumably Socrates and his interlocutors would say in effect that the laws of physics also matter. 
could be such an approximation somewhere sometime. And that has considerable implications for a relatively wide range of interpretations of the Republic, as I will underscore in the final section. My aim here is to take a much closer look than any available at the issue of possibility in the Republic, and to show that Socrates and his interlocutors act in accordance with what I shall call the possibility requirement: A polis built in speech is not the best city unless it is possible.

\section{The Possibility Requirement Prior to 472b3-473b3}

Commentators such as Schofield 2006, 239, Brown 2000, 14, and Annas 1999, 80 deny that the possibility of the aristocratic city is an integral concern in the Republic. Their denial is based on an appeal to Republic 472b3-473b3 and 592a7-b6. Apparently, these commentators would say that if possibility plays a significant role in the dialogue prior to $472 \mathrm{~b} 3-473 \mathrm{~b} 3$, Socrates and his interlocutors substantially change direction at that point in a way that renders possibility irrelevant. I think it is incorrect to hold that the issue of possibility drops out after $472 \mathrm{~b} 3-473 \mathrm{~b} 3$, and I will argue as much in the next section below. But first I want to show that prior to $472 \mathrm{~b} 3-473 \mathrm{~b} 3$, the possibility requirement is, indeed, in place.

To begin with, consider the context in book 5 in which $472 \mathrm{~b} 3-473 \mathrm{~b} 3$ appears. At the start of book 5, Socrates' interlocutors interrupt him. They protest that he has not adequately supported his claim that the aristocratic city that he and they have built in speech is the just polis. Effectively conceding, Socrates quickly confesses that 'it's not easy' (450c6) to fill out the argument fully enough. And as if to explain why is conceding, he highlights the question of whether the aristocratic city is possible-meaning, at this point, whether it could come to be despite the constraints of the material realm or also the constraints of the immortal soul-and he talks as if the account given so far in the dialogue has a serious problem if the city, in fact, could not come to be: 'For it could be doubted that the things said are possible ( $\delta v v \alpha \tau \alpha)$; and even if in the best possible conditions they

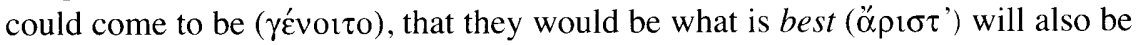
doubted. So that's why there's a certain hesitation about getting involved in it, for fear that the argument might seem to be a prayer ( $\left.\varepsilon \dot{v} \chi \eta^{\prime}\right)$, my dear friend' $(450 \mathrm{c} 8-\mathrm{d} 2) .{ }^{8}$ Socrates soon agrees to 'go back again and say what perhaps should

${ }^{8}$ At 472a8-b2, e.g., Glaucon pressures Socrates to tell "how it is possible for this regime to come

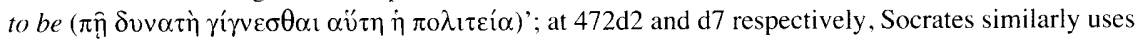
the phrases $\delta v v \alpha \tau \dot{\alpha} \tau \alpha \hat{v} \tau \alpha \gamma^{\prime} \gamma v \varepsilon \sigma \theta \alpha \mathbf{l}$ ('possible for these things to come to be') and $\delta v v \alpha \tau o \dot{v}$

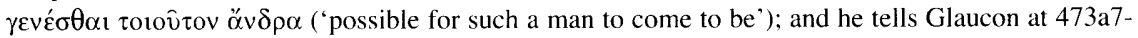
b1: 'If we're able to find how a city might be managed most closely to what's been said, say that we've found the possibility of these things' coming to be on which you insist ( $\delta v v \alpha \tau \dot{\alpha} \tau \alpha \hat{v} \tau \alpha$

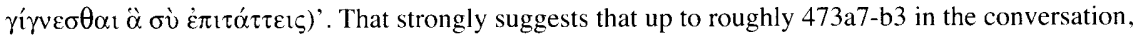
the issue about possibility is about whether the city under discussion could come to be. Accordingly, unless there is good reason to think that the talk of possibility in that part of the dialogue is about something else instead, the most sensible conclusion is that that is what it concerns. On another point, at $457 \mathrm{~d} 8-9$, too, it is Socrates who makes the distinction between whether a certain way of structuring the polis would be best and whether it would be possible, and when Glaucon at 471c4-e5 demands 
have been said then in its turn' (451b9-cl; cf. his confession at 502d4-8). Thereupon, he and Glaucon agree to investigate first whether it is possible, and then whether it is best, to structure the polis in the ways Socrates has proposed (452e4-453a6; cf. 456c4-10), for example, whether it is possible to have women exercise naked with men in the palaestras. The conversation then proceeds accordingly. Glaucon ends up consenting that when it comes to the prospect of having female guardians who share all pursuits with the male guardians, 'we weren't giving laws that are impossible ( $\alpha \delta \dot{v} v \alpha \tau \dot{\alpha})$ or like prayers ( $\varepsilon \dot{v} \chi \alpha i \varsigma)$ ' (456b12). And perhaps most revealing, he also assents that nothing is 'better for a city than the coming to be in it of the best possible ( $\dot{\omega} \varsigma \dot{\alpha} \rho \dot{\sigma} \sigma \tau \tau_{\zeta}$ ) women and men' (456e6-7; cf., e.g., $416 \mathrm{c} 7$ with 428d12, though also, e.g., 421c1-2); that what he and Socrates have just discussed would ensure the production of such women and men; and that that law 'is therefore not only possible, but also best'

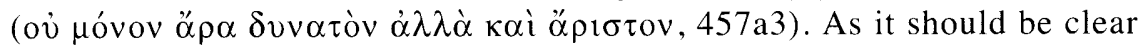
enough, Socrates and his interlocutors talk here as if a particular way of structuring a city (or a city structured in that way) has to be possible in order to be best

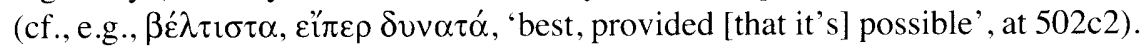
That is, Socrates and his interlocutors adhere to the possibility requirement.

And that is perfectly in keeping with all the passages in the dialogue that precede this passage. In that whole stretch of the dialogue, Socrates and his interlocutors never seek a political order that is ideal by virtue of the Forms alone, and their search for the ideal political order is always guided by empirical considerations. ${ }^{9}$ Even at the very outset of the discussion of good cities, after Socrates has said: 'Come, now, let's make a city in speech from the beginning' (369c9-10), the first thing he goes on to say is: 'Well, now, the first and greatest of needs is the provision of food for existing and living' (369d1-2). In a phenomenal city, people need food, there are children who can be corrupted by corruptive poetry, faction can arise, and so on. And perhaps if there is, indeed, a paradigm (or, model, $\pi \alpha \rho \alpha \dot{\alpha} \delta \varepsilon \gamma \mu \alpha)$ of the just city laid up in heaven, as Socrates says at 592b23 there might be - and if paradigms of that sort are (in one way or another) distinct from Forms, as one can cogently argue they are (see Burnyeat 1999, 297-299; cf. Dorter 2006, 302-304; Ferrari 2003, 105-106) - the paradigmatic just city also suffers similar complications. But on Socrates and his interlocutors' terms, it would be a proper standard by which to measure the justice of phenomenal cities only insofar as it accurately represented the Forms. And there is no need for food, for example, among Forms. One considers such needs in this con-

that Socrates finally address the feasibility of what has been proposed, what Glaucon alludes to is the point earlier in the conversation (457e 7-458b7) at which Socrates-unlike on previous occasionsasks Glaucon to let him set aside for a moment the question of possibility.

${ }^{9}$ This is the case in spite of, e.g., 532a6, Phaedo 65e8-66a1. I recognize that Socrates has not yet introduced overt talk of the Forms in this stage of the dialogue. I make the point here above simply in case this part of the conversation is to be read in light of the parts in which overt talk of the Forms does appear. Note, Annas 1981, 234 claims that 'in Books 5 and 10 Forms are brought in as being already accepted by all the interlocutors, though they are new to the reader. The same happens at 505a with the Form of the Good'. 
text only if one is trying to determine what is possible given the constraints of the phenomenal realm or also the immortal soul.

Moreover, if a city does not have to be possible in order to be best, then to shape a paradigmatic city in light of those constraints is to misshape it; for in that case, the proper paradigm of the best city might be simply the best city conceiv$a b l e$. As long as it is genuinely best, the best city conceivable can be purely fantastical in every other respect. A wide range of counterfactual states of affairs are readily conceivable (Superman, Homeric and Hesiodic gods - anything but square circles). Plus, anything or anyone conceivable can be built in speech. If, for example, citizens must have needs in order for a city to be founded and be cohesive (369b5-8), Socrates and his interlocutors could satisfactorily describe a polis in which everyone requires only, say, a chance to love other people and be loved in return. And if any constraints at all are imposed by the phenomenal realm or also the immortal soul, the best conceivable city is sure to be better, so to speak, than the best possible city.

In any case, in this whole stage of the dialogue - from the point at which Socrates and his interlocutors start to build a city in speech, and up to roughly 473a7-b3-they talk as if the best polis is the envisioned city that has the most preferable, beneficial, or advantageous features that a phenomenal city could have: on Socrates and his interlocutors' terms here, a city built in speech is best only if it could be replicated in the phenomenal world. For that matter, they not only proceed as if they have to meet the possibility requirement but also they do so quite conspicuously, and in the Republic as a whole this requirement plays a major role in shaping their conversation. In much of the Republic, they work assiduously to build a regime capable of performing the functions they ascribe to the aristocratic city, and Socrates and his interlocutors tweak one aspect after another of the aristocracy. In book 2 , they end up saying that the feverish city needs more craftsmen than the healthy city needed, and more land and, thus, guardians, and that the guardians need to be philosophic in nature (373b-376c). The question becomes how properly to educate the guardians so that they will be both gentle enough with people in the city and suitably ferocious toward enemies outside the city (see $416 \mathrm{a} 2-\mathrm{d} 4$ ). The vast majority of the conversation at $369 \mathrm{~d} 1-$ $427 \mathrm{c} 5$ has to do with how the potential guardians could be shaped into suitable rulers. And in book 5, after Glaucon ends up agreeing to search for the closest approximation to the ideal city, the conversation virtually returns to the question of whether there could be suitable rulers of the aristocratic city, and it then lingers on that question through the end of book 7 .

\section{Is the Possibility Requirement Cancelled at 472b3-473b3?}

I have argued that the possibility requirement is in place prior to $472 \mathrm{~b} 3-473 \mathrm{~b} 3$. But certain commentators would say that a substantial shift occurs at 472b3$473 \mathrm{~b} 3$ that reverses whatever role the possibility issue played up to that point in the dialogue. They suppose that the possibility requirement is in effect cancelled at $472 \mathrm{~b} 3-473 \mathrm{~b} 3$, and in the subsequent discussion possibility is irrelevant. The 
case for this view appears bolstered by the claim at 592a7-b6. So let me address those two passages.

At 592a7-b6, Socrates and his interlocutors seem to agree with each other that the aristocratic city 'has its place in speeches' and is 'nowhere on earth' (a11), and that probably (b6) 'it doesn't make any difference whether [that city] is or will be somewhere' in the phenomenal world (b3-4). And at 473a7-b2, while insisting that the aim should be simply to draw in speech an appropriate paradigm $(\pi \alpha \rho \alpha \delta \varepsilon \imath \gamma \gamma \mu \alpha)$ against which to measure the justice of particular men and cities in the phenomenal world, Socrates declares:

If we're able to find how a city might be managed most closely to what's been said, say that we've found the possibility of these things' coming to be on which you insist ( $\dot{\varepsilon} \alpha{ }^{2}$ oîoi $\tau \varepsilon$

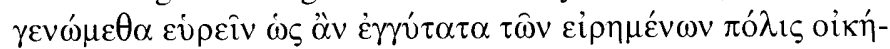

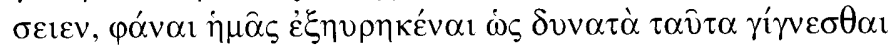
$\ddot{\alpha} \sigma \dot{v} \dot{\pi} \pi \tau \dot{\alpha} \tau \tau \varepsilon ı \zeta)$. Or won't you be satisfied if it turns out this way? I, for my part, would be satisfied.

Glaucon replies that so would he (473b3), and no one else objects. It might seem that here the possibility requirement is effectively cancelled-in other words, that Socrates and his interlocutors substantially change direction at this point, now simply rejecting the view that a city or a way of structuring it has to be possible in order to be best. The thought would be that on their terms after 473a7-b3, the point is just to describe the best conceivable city, and the best phenomenal city is simply the one that most fully resembles it, whatever phenomenal city that might turn out to be (see Schofield 2006, 239). Taking up that thought, we might say that if the Republic concerns politics at all, instead of just the soul, perhaps the purpose of looking to a paradigm of justice is simply to make a democracy or some other non-aristocratic phenomenal regime as much like the paradigmatic aristocracy as possible.

To the contrary, I claim that rather than being cancelled, at 473a7-b3 the possibility requirement is only adjusted somewhat and is effectively left intact. Even after 473a7-b3, on Socrates and his interlocutors' terms a city is best only if it is possible, so in part we are to look to the phenomenal world in gauging whether a paradigm drawn in speech is the right standard of justice. The point at $472 \mathrm{~b} 3-$ $473 \mathrm{~b} 3$, I maintain, is simply that the appropriate test of possibility is not whether there could be a phenomenal replica of the city they have built in speech. ${ }^{10}$ On my view, Socrates and his interlocutors proceed after $472 \mathrm{~b} 3-473 \mathrm{~b} 3$ as if it has to be feasible to originate a sufficiently similar city: unless a standard could be approximated closely enough in the phenomenal world, the standard is not the appropriate paradigm of justice. ${ }^{11}$ My view might seem surprising. Why is it clear enough that the possibility requirement is not in fact cancelled at $473 \mathrm{a} 7-\mathrm{b} 3$ ?

${ }^{10}$ For why it is plain enough that possibility is what is to be tested, see, e.g., 472e8, 473a 7 -b1, $502 \mathrm{c} 2,540 \mathrm{~d} 3,541 \mathrm{~b} 8$.

11 As I mention in the final section below, it is not clear just how close of an approximation is close enough on Socrates and his interlocutors' terms. 
Note first that on its own 592a7-b6 is relatively ambiguous. It can be read to have a much more modest meaning than we might suppose. The claim that the aristocratic city 'has its place in speeches' and is 'nowhere on earth' (a11) can be read to mean simply that no such polis exists at present-and not that no such city could ever come to be. And with regard to the claim that probably (b6) 'it doesn't make any difference whether [that city] is or will be somewhere' in the phenomenal world (b3-4), we can say the point is not that the feasibility or infeasibility of that city is immaterial simpliciter, but that even if the aristocratic city is impossible it can still be of use to the man whom Socrates and Glaucon discuss at $591 \mathrm{c}-592 \mathrm{~b}$ - the intelligent man who works toward the proper development of his soul and, accordingly, wants to found within himself a city like the aristocratic polis (cf. 592b2-3).

By itself the flexibility of 592a7-b6 does not count for much. But in light of certain other features of the dialogue, 592a7-b6 needs to be interpreted along the more modest lines just mentioned. If after $473 \mathrm{a} 7-\mathrm{b} 3$ the point were simply to favor the phenomenal city that most fully resembles the paradigm (whatever city it might turn out to be), then it would be difficult to account for how Socrates' statement at 473a7-b1 begins: 'If we're able to find how a city might be managed most closely to what's been said, say that we've found the possibility of these things' coming to be on which you insist.' Socrates seems to talk as if there still will be a test of possibility. And what value can a test have here unless Socrates and his interlocutors take up the task of establishing that there could be a phenomenal city similar enough to the city built in speech? Inevitably, some phenomenal city or cities would be more similar than other phenomenal cities are (and thus 'closest' to the paradigm). Plus, unless the task is to show that a phenomenal city could be similar enough, it also is difficult to account for what happens next in the dialogue. At 473b4-cl, Socrates and Glaucon agree that now they must try to establish what it would take for the closest approximation to come to be, and part of what they then go on to discuss at considerable length is whether too much is required (see, e.g., 541a8-b1).

If the possibility requirement were cancelled at 473a7-b3, then in telling Glaucon at 473a8-b1: 'Say that we've found the possibility of these things' coming to be on which you insist', Socrates would mean: 'Just forget about whether they're possible. It doesn't matter.' But if that were what he meant, it would be strange that he indicates at 472e6-9 that he is going to try to demonstrate ( $\dot{\alpha} \pi \circ \delta \varepsilon \hat{\imath} \xi \alpha 1, \mathrm{e} 7)$ possibility; and it would be no less odd that at $540 \mathrm{~d}-541 \mathrm{~b}$, at the close of the phase of discussion that immediately follows 473a7-b3, he gets Glaucon to affirm that at that point possibility has been argued for cogently enough. Plus, $540 \mathrm{~d}-541 \mathrm{~b}$ fits with a number of references to possibility that appear between 473a7-b3 and 540d-541b. Perhaps most striking is the phrase $\beta \varepsilon \dot{\prime} \lambda \tau \imath \sigma \tau \alpha$, عí $\pi \varepsilon \rho$

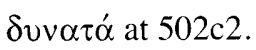

In starting his statement at $472 \mathrm{e} 6-9$ by saying: 'If, then, to gratify you I must also strive to prove how and under what condition it would be most possible' ['to found a city the same as the one in speech', 472e4], Socrates might seem to sug- 
gest that possibility is to be demonstrated only for the purpose of gratifying Glaucon - in other words, that Socrates will put Glaucon's concerns to rest simply for the sake of going the extra mile. And in light of 472b7-e5-that is, the passage leading up to 472e6-9 - it might look as if Socrates is just particularly accommodating here. We might think that already at $472 \mathrm{~b} 7$-e 5 - even putting aside $473 \mathrm{a} 7$ b3 - he effectively gets Glaucon to agree that possibility need not be demonstrated.

But first, like 592a7-b6 discussed above, on its own 472b7-e5 is relatively ambiguous. Although 472b7-e5 can be read in the way I just pictured, it surely does not have to be read that way. The claims at 472b7-c3 and 472e 3-5 can be legitimately seen as consistent with the view that a city built in speech is not best unless it could be approximated closely enough in the phenomenal world. At 472b7-cl, all Socrates asks Glaucon is: "If we discover what sort of thing justice is, will we also insist that the just man must not differ at all from justice itself

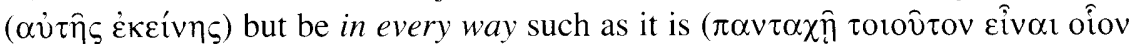

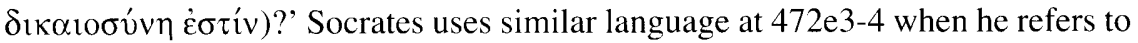
the possibility of founding a city 'the same as the one in speech' (oú $\tau \omega . . . \dot{\omega} s$ $\varepsilon \lambda \varepsilon \dot{\varepsilon} \varepsilon \tau 0,472 \mathrm{e} 4) .{ }^{12}$ And especially in light of that (and partly since 472d4-7 picks up on the idea pervading $472 \mathrm{c} 4-\mathrm{d} 3$ of a $\pi \alpha \rho \alpha \delta \varepsilon \imath \gamma \mu \alpha)$, when Socrates asks at 472d4-7, 'Do you think any less of a painter who draws a paradigm of what the fairest human being would be like and renders everything in the picture adequately but can't prove that it's also possible for such a man to come to be?', it makes plenty of sense to think Socrates means that what the painter cannot prove the possibility of is a man of exactly that sort. By virtue of that, what Glaucon effectively affirms at $472 \mathrm{~d} 8$ can be seen as consistent with the view that a city built in speech is not best unless it could be approximated closely enough in the phenomenal world.

By itself the flexibility of $472 \mathrm{~b} 7-\mathrm{e} 5$, like that of 592a7-b6, is hardly decisive. But 472b7-e5 needs to be interpreted in the way I just suggested, for there is a compelling reason to deny that in that passage Glaucon is led to assent that demonstrating possibility is unnecessary. If Socrates and his interlocutors cancelled the possibility requirement at any stage within $472 \mathrm{~b} 3-473 \mathrm{~b} 3$, it would be hard to explain their behavior in the whole rest of the dialogue. For if a city does not have to be possible in order to be best, then the city built in speech prior to 472b3-473b3 should be scrapped entirely. After all, as I have emphasized, from the point at which Socrates and his interlocutors first start to build a city in

12 Strictly speaking the claims at 472c4-d3 can be legitimately seen as consistent even with the view that a city built in speech is not best unless it could be replicated in the phenomenal world. At 472c4-d3, Socrates gets Glaucon to assent that the point of the search so far - the search for "what justice by itself is like' and 'the perfectly just man, if he should come into being, and what he should be like once he came into being; and in their turns, for injustice and the most unjust man' - has been to find a paradigm, rather than to prove the possibility of the city built in speech. And even if doing $X$ is not the point of carrying out a particular task-i.e., even if doing $X$ is not that for the sake of which the task is carried out - it can still be necessary for carrying out that task successfully. 
speech in book 2 , and up to $472 \mathrm{~b} 3-473 \mathrm{~b} 3$, they shape their city in light of what they think the constraints of the phenomenal world or also the immortal soul are. In the absence of the possibility requirement perhaps all they should describe is the best city conceivable.

Yet plainly enough, after $472 \mathrm{~b} 3-473 \mathrm{~b} 3$ Socrates and his interlocutors hardly scrap everything said before then about what the just city is. On the one hand, from passages such as 473b4-c1,540d1-3, and 541a8-b1, it is evident enough that the topic that Socrates and his interlocutors start to discuss with each other at $473 \mathrm{c} 2$ is the 'closest' approximation to the original aristocratic city (meaning the aristocratic city described prior to $472 \mathrm{~b} 3-473 \mathrm{~b} 3$ ) allowed by the constraints of the phenomenal realm or also the immortal soul (that is, the city referred to at 473a7-8 as the closest approximation). On the other hand, on Socrates and his interlocutors' terms the most substantial difference between the closest approximation and the original aristocratic city is simply that the closest approximation is explicitly said to have rulers who are philosophers. The clearest testament to that is the fact that in book 6, well after 472b3-473b3, when Socrates refers to the regime within the closest approximation, Glaucon asks 'whether it's the same one we described in founding the city' (497c5-6), and Socrates replies that 'it's the same in the other respects and in this very one, too, which was stressed in connection with it - that there would always have to be present in the city something possessing the same logos of the regime as you, the lawgiver, had when you were setting down the laws' (497c7-d2). The exchange that then follows makes it evident enough that on Socrates and his interlocutors' terms the most substantial addition to the conversation is simply the explicit talk of philosopherkings. Perhaps the closest approximation is numerically distinct from the aristocratic city described prior to $472 b 3-473 b 3$, as $543 c 7-544 b 4$ can seem to suggest it is. Perhaps, instead, in line with what $497 \mathrm{~d} 4$ can seem to suggest, the conversation that follows $472 \mathrm{~b} 3-473 \mathrm{~b} 3$ simply explicates a certain feature of the aristocratic city that it already had (contrast, e.g., Brown 2003, $\$ 4.1$ with Reeve 1988, $170,172,186 \mathrm{ff}$.). But whether one city is replaced with another or, instead, the difference is just between what is explicitly said before $472 \mathrm{~b} 3-473 \mathrm{~b} 3$ and what is explicitly said thereafter, on Socrates and his interlocutors' terms the shift is far from radical, despite how consequential it is.

I should add that even after 472b3-473b3 Socrates and his interlocutors never voice any doubt that the city should perform the functions that they as early as book 2 assumed it should perform (for example, the shaping children's education and rearing so that there will be rulers ferocious enough toward the city's enemies but sufficiently gentle with its citizens) or that in order to perform those functions the city needs to have the features they name prior to $472 \mathrm{~b} 3-473 \mathrm{~b} 3$, such as the sharing of women and children. The point of adding philosopherkings into the equation is to ensure that the city can perform those functions by those means (see 423e4-6; cf. Schofield 1999, 37). After all, the official aim of the discussion that runs from $473 \mathrm{c} 2$ through the end of book 7 is simply to establish that there could come to be a city in which women and children were 
shared. ${ }^{13}$ Plus, the overarching claim made within the discussion running from $473 \mathrm{c} 2$ through the end of book 7 , where Socrates and his interlocutors agree that the aristocratic city is possible, is that philosopher-rulers could come to be (and that once they came to power they would exile everyone else over the age of ten and rear the remaining children 'far away from those dispositions they have now from their parents', 540e5-541b1). Presumably, the reason that the feasibility of philosopher-rulers is supposed to translate into the feasibility of sharing women and children is that philosopher-rulers would decide that women and children would be shared (and philosopher-rulers would not face too much resistance in acting on that decision).

\section{What Rides on Whether the Closest Approximation Could Come to Be?}

It is significant that Socrates and his interlocutors adhere to the possibility requirement throughout the Republic, for on their terms, if they are to argue that the aristocratic city is the just polis, they need to argue successfully that the closest approximation could come to be. More specifically, the extent to which they support their claim about what justice is in the polis depends crucially on the extent to which they support the claim that the closest approximation could come to be, and they support the former claim only if they support the latter claim.

Granted, perhaps a city can be just even if it is neither possible nor best; and for all we know, Socrates and his interlocutors would say that it can be. Although they proceed as if a city has to be possible in order to be best, it is not clear that on their terms a city has to be possible in order to be just: we are left only to guess whether they would say it does. And they also never claim that a city has to be best in order to be just. ${ }^{14}$

Further, the aristocratic city might be possible even if the closest approxima-

${ }^{13}$ As evidence: (1) Part of what Socrates and his interlocutors agree at $543 \mathrm{al}-\mathrm{c} 4$ is that a city is 'governed on a high level' only if it is a polis in which women and children are in common. (2) This aspect of 543al-c4-coupled with $458 \mathrm{~b} 8$, where Glaucon consents when Socrates proposes to talk first about the advantageousness of sharing women and children, before talking about its possibility suggests that at $471 \mathrm{c} 4-\mathrm{e} 5$ Glaucon is content enough that sharing women and children is best provided that it is possible: its possibility is the one remaining issue there in the current phase of the conversation. Plus, (3) when Glaucon presses that issue at $471 \mathrm{c} 4-\mathrm{e} 5$, Socrates soon agrees to try to demonstrate possibility.

14 We might understandably assume that they would make that claim. In book 4 they seem to agree that the just polis is a city in which each citizen performs strictly the function for which he is naturally fit (see esp. 433a5ff.); and it certainly is tempting to think that on Socrates and his interlocutors' terms the best state of affairs is simply one in which everything does its proper ergon and thereby accords with nature. Yet there plainly are cases in which Socrates and his interlocutors talk as if accordance with nature is not a sufficient condition of bestness. E.g., at 456c9-10 - just after Glaucon has virtually affirmed again that the laws Socrates has proposed are possible because they accord with nature (456c7-8; cf. 456b12-cl)-Socrates gets him to consent also that since they have now decided that those laws are possible, next they must consider a different question-viz., whether those laws are best ( $\beta \dot{\varepsilon} \lambda \tau 1 \sigma \tau \alpha, 456 \mathrm{c} 9$ ). Admittedly, what Socrates and Glaucon mean at $456 \mathrm{c} 9-10$ in speaking of accordance with nature might be different from what they mean at $444 \mathrm{~d} 3-12$. But perhaps it is the same. 
tion could not come to be; and for all we know, if someone were to show Socrates and his interlocutors that it could not, they might still argue that the aristocratic city is possible. One reason is that it is not clear just how much like an original city an approximation supposedly has to be in order to resemble it 'enough'; the Republic affords no firm answer. Though, for example, we can rightly say that Socrates and his interlocutors proceed as if the original aristocratic city (meaning, again, the aristocratic city described prior to 472b3-473b3) is possible as long as the closest approximation could come to be, we would go beyond what the Republic gives us if we made the additional claim that on their terms the original aristocratic city is possible only if the closest approximation could come to be.

And here is another reason. First, they end up treating the closest approximation as the best city (that is, as the best possible city), though Laks 1990, 215-216 talks as if they do not. Of course in this context one expects an approximation to be less desirable than what it approximates. Plus, (1) at first, such as at 473a7-b3, the candidate for the best city is the original aristocratic polis; (2) at 473a7-b3 Socrates and his interlocutors agree that the original aristocratic city is possible if it could be approximated closely enough in the phenomenal world; (3) by 473c2 their agreement effectively is to build in speech a polis similar to the original aristocratic city (in other words, the agreement is to approximate the original aristocratic city in speech) and to investigate whether the newer city could be replicated in the phenomenal world; ${ }^{15}$ and (4) by at least $543 \mathrm{~d}$ they have agreed that the closest approximation could come to be. But at $497 \mathrm{~b} 7 \mathrm{ff}$. Socrates refers to the political order within the closest approximation as 'the best regime' ( $\tau \dot{\eta} v$ $\dot{\alpha} \rho \dot{\sigma} \sigma \eta v \pi \mathrm{o} \lambda 1 \tau \varepsilon i \alpha v)$. And at 543d1-544al Glaucon says that the closest approximation seems to be 'still finer' than the original aristocratic city.

I take no position on whether the closest approximation is supposed to be numerically identical to the original aristocratic city. But if it is, then in effect Socrates and his interlocutors' claim about possibility is ultimately this: The original aristocratic city could be not just approximated closely enough in the phenomenal world, but replicated there. And if the closest approximation is supposed to be numerically distinct from the original aristocratic city, then in effect Socrates and his interlocutors' claim is ultimately this: Regardless of whether the original aristocratic city could be approximated closely enough in the phenomenal world, a certain preferable aristocratic city could be replicated there. So either way, regarding the aristocratic city which by the end of the dialogue they treat as the best polis, their claim is that it is possible because it could come to be. And for all we know, perhaps they would say that that claim is stronger than it has to be. Since, to repeat, at 473a7-b3 they agree that the original aristocratic

15 The issue is not whether the closest approximation could itself be approximated closely enough in the phenomenal world. And that is appropriate, after all, since the original aristocratic city could be approximated closely enough in the phenomenal world only if a sufficiently similar phenomenal city could come to be. So, in light of 473a7-b3 and 540d-541b, the $\delta v v \alpha \tau \alpha$ at $502 \mathrm{c} 2$ is most sensibly read as meaning 'could come to be'. 
city is possible even if it could just be approximated closely enough in the phenomenal world, we are left to think that if they came to the conclusion that the closest approximation could not come to be they might say it still is possible as long as it could be approximated closely enough in the phenomenal world: we are left to think they might say that, as a general principle, whatever the best city turns out to be it is possible as long as there could be (at least) a close enough phenomenal approximation to it. ${ }^{16}$

In any case, I acknowledge that if someone were to show them that the closest approximation could not come to be, perhaps they would say, 'No matter - the just city is still is what we've said it is' and then go on to give an argument for that claim. Nonetheless, here it scarcely matters whether they would, for no such argument appears in the dialogue. In fact, (1) Socrates and his interlocutors infer the aristocratic city's justice from its bestness. Part of what they explicitly agree at $427 \mathrm{e} 10-12$ is that since the aristocratic city is 'completely good' ( $\tau \varepsilon \lambda \dot{\varepsilon} \omega \varsigma$ $\dot{\alpha} \gamma \alpha \theta \eta \dot{v} v$ ) it must be just. And they do not argue that the aristocratic city is just even if it is not best - the only relevant case they make for the aristocratic city's justice is that the aristocratic city is the best polis; so unless they argue successfully that it is best, they fail to argue successfully that it is just. (2) In the absence of the possibility requirement, perhaps all they should describe is the best city conceivable. And (3) their argument that the closest approximation could come to be is the only relevant case they ultimately make in trying to meet the possibility requirement. Hence on their terms, the extent to which they support the claim about what justice is in the polis depends quite heavily on the extent to which they support the claim that the closest approximation could come to be-so heavily that if the case they make for the latter claim happened to collapse, so would all their support for the former claim.

It should be easy enough to see that this is no small matter. At the least, it is far more significant than certain recent commentators would lead us to think (see especially note 4 above). If in arguing that the aristocracy is the just regime they do take on the task of supporting the view that somewhere sometime there could be a close enough phenomenal approximation to the aristocratic city they describe, and if the argument voiced in the Republic is in other respects what most readings say it is, then the argument is exceedingly harder to defend than it otherwise would be, since it is far from clear how the argument comes anywhere close to doing the work it is supposed to do. On some of those readings, the Republic is ultimately supposed to support the view that being just is always more profitable for an individual person than being unjust is, and the extent to which Socrates and his interlocutors support that view depends on the extent to which they support the view that the aristocratic city is the just polis. By contrast,

16 The most that 473c11-e2 and 546al-547a5 would show is that on Socrates and his interlocutors' terms no aristocratic city described in the dialogue is possible unless there could be a phenomenal city ruled by philosophers who calculated the birth number as well as the rulers in Socrates and his interlocutors' description do (and not that a phenomenal city would have to have also all the other features that the closest approximation has). 
other of those interpretations can seem to say that although the Republic is ultimately meant to support both of those views, it does not have to demonstrate the justice of the aristocratic city in order to show the superiority of being just. ${ }^{17}$ Yet on all of these readings, obviously, the extent to which the Republic can serve its ultimate purpose depends on the extent to which the political thesis is supported. And even if Annas 1999, 82 overstates the point, no doubt there is something to her claim that the political proposals voiced in the Republic 'are absurd if the details are taken literally'. At the least, it is pretty difficult to see how the political proposals could be carried out. At 540e5-541b1, for example, Socrates gets Glaucon to agree that when the true philosophers become rulers (540d3-4) they will exile everyone else over the age of ten and rear the children who remain. Yet how could the philosopher-rulers get all those elders to leave the city? ${ }^{18}$ Without question, there can be acceptable interpretations of a Platonic dialogue on which Plato's arguments fall short of being sound. But presumably, of course, the arguments that an interpretation ascribes to a Platonic dialogue are supposed to be free of major deficits - at the least, the interpretation should avoid suggesting that the dialogue's author is philosophically frail. And it will not do to plead that the claim about the aristocratic city's possibility is an extraneous or incidental feature of the argument voiced in the Republic, for in the absence of the possibility requirement perhaps all that Socrates and his interlocutors should describe is the best city conceivable. In short, the role of the possibility requirement in the Republic poses a genuine challenge for the readings I have just mentioned. ${ }^{19}$

${ }^{17}$ For Kraut 1997, 217-218n11 the analogy between polis and psuche at 434-442 is supposed to show what the soul's justice is: from the fact that the just polis is a city in which each part does strictly its proper work such that reason rules the whole, it is supposed to follow that justice in the soul consists of each part's functioning only as it should, with the reasoning part at the helm. For an opposing view, see Annas 1981, 151, 185.

18 Also troublesome is the view that the pupils in the aristocratic city who have been turned from the phenomenal world to glimpse fully what is will have to be compelled to go back down into the cave in order to rule there (see 500d4-8, 519el-520a4, 520a6-9, e1-4, 521b7-11, 539e2-5, 540b2-5 with Brown 2004, 295n 25 and Brown 2000, 5-9). If the desire for a maximally happy city would not be enough to motivate philosophers to rule in a phenomenal city like the aristocratic polis, then as Brown 2000, 13 asks why should anyone else be sufficiently motivated to found a phenomenal approximation to it in the first place? On another point: The view that unless we have received the rigorous education in mathematics prescribed in the Republic we cannot recognize that the aristocratic city is possible (see Brown 2000, 14n38 and Burnyeat 2000,64) is at odds with Socrates and his interlocutors' claim that the aristocratic city is possible. It thus seems strange that Brown and Burnyeat talk as if the aristocratic city's 'practicability' is demonstrated in the dialogue.

${ }^{19}$ If I am correct, no less problematic are readings on which Socrates and his interlocutors' talk about individual justice is just a pretext for discussing the politeia (see 8.7-11.4 of Proclus' commentary on the Republic). The role of the possibility requirement counts decisively against the interpretation of the Republic offered by Strauss 1964, 50-138. On Strauss' interpretation part of the ultimate purpose of the Republic is to teach readers the mistakenness of trying to build a fully just city in this world, i.e., to purge us of the ambition to make our polis into all that a city should be (even if some approximation of political justice is worth seeking). But on Socrates and his interlocutors' terms in the Republic, if we envision a city which has features that appear to be the most preferable, beneficial, or advantageous - yet we determine that a phenomenal city could not have those features - what we 
There are, then, notable implications if Socrates and his interlocutors honor the possibility requirement. It is clear enough that they do. To make a decent case that they do not, one has to say that the possibility requirement is cancelled at 472b3-473b3. But in that passage, Socrates and his interlocutors simply adjust the possibility requirement somewhat, effectively leaving it intact. Even by the dialogue's end, they act as if a city built in speech is not best unless it is possible. It makes a significant difference for their argument whether, somewhere sometime, there could be a close enough phenomenal approximation to the aristocratic city built in speech. ${ }^{20}$

Philosophy Program

Humanities and Teacher Education Division

Pepperdine University

Malibu CA 90263

\section{BIBLIOGRAPHY}

Annas, Julia. 1981. An Introduction to Plato's 'Republic'. Oxford: Clarendon Press.

Annas, Julia. 1999. Platonic Ethics, Old and New. Ithaca: Cornell University Press.

Blackburn, Simon. 2006. Plato's 'Republic': A Biography. London: Atlantic Books.

Bloom, Allan, trans. 1968. The 'Republic' of Plato. 2nd edn. New York: Basic Books.

Brown, Eric. 2000. 'Justice and Compulsion for Plato's Philosopher-Rulers' Ancient Philosophy 20: $1-17$.

Brown, Eric. 2003. 'Plato's Ethics and Politics in the Republic' in Edward N. Zalta ed. The Stanford Encyclopedia of Philosophy <http://plato.stanford .edu/entries/plato-ethics-politics $>$.

Brown, Eric. 2004. 'Minding the Gap in Plato's Republic' Philosophical Studies 117: 275-302.

Burnyeat, M.F. 1999. 'Utopia and Fantasy: The Practicability of Plato's Ideally Just City' 297-308 in Gail Fine ed. Plato. vol. 2. Ethics, Politics, Religion, and the Soul. Oxford: Oxford University Press.

Burnyeat, M.F. 2000. 'Plato on Why Mathematics is Good for the Soul' Proceedings of the British Academy 103: 1-81.

Demos, Raphael. 1957. 'Paradoxes in Plato's Doctrine of the Ideal State' Classical Quarterly N.S. 7: 164-174.

Dorter, Kenneth. 2006. The Transformation of Plato's 'Republic'. Lanham: Lexington Books.

Ferrari, G.R.F. 2003. City and Soul in Plato's 'Republic'. Lecturae Platonis 2. Sankt Augustin: Academia Verlag.

Gerson, Lloyd P. 2003. Knowing Persons: A Study in Plato. Oxford: Oxford University Press.

Guthrie, W.K.C. 1975. A History of Greek Philosophy. vol. 4. Plato: The Man and His Dialogues: Earlier Period. Cambridge: Cambridge University Press.

Kraut, Richard. 1997. 'The Defense of Justice in Plato's Republic' 197-222 in R. Kraut ed. Plato's 'Republic': Critical Essays. Lanham: Rowman and Littlefield.

Laks, André. 1990. 'Legislation and Demiurgy: On the Relationship Between Plato's Republic and Laws' Classical Antiquity 9: 209-229.

Lorenz, Hendrik. 2006. The Brute Within: Appetitive Desire in Plato and Aristotle. Oxford: Clarendon Press.

have discovered is not that the best city could not come to be. The upshot, rather, is that we have simply failed to identify what the best city is.

${ }^{20}$ Thanks to Scott Aikin, Mark Anderson, John Lachs, Aaron Simmons, Peter Simpson, the anonymous referees from Ancient Philosophy, and especially Henry Teloh and Robert Talisse for helpful comments on earlier drafts of this article. 
Moline, Jon. 1981. Plato's Theory of Understanding. Madison: University of Wisconsin Press.

Reeve, C.D.C. 1988. Philosopher-Kings: The Argument of Plato's 'Republic'. Princeton: Princeton University Press.

Schofield, Malcolm. 1999. Saving the City: Philosopher-Kings and Other Classical Paradigms. London: Routledge.

Schofield, Malcolm. 2006. Plato: Political Philosophy. Oxford: Oxford University Press.

Strauss, Leo. 1964. The City and Man. Chicago: University of Chicago Press.

White, Nicholas P. 1979. A Companion to Plato's 'Republic'. Indianapolis: Hackett. 